OBITUARY.

\title{
HENRY FRANKLIN PARSONS, M.D., F.G.S.
}

\author{
BORN FEBRUARY 27, $1846 . \quad$ DIED OCTOBER 29, 1913.
}

We much reglet to record the death, at the age of 67 , of Dr. Franklin Parsons, F.G.S., a medical officer who was distinguished for his extensive knowledge and wide experience of sanitary science, who was an enthusiastic worker in geology, and an expert botanist.

He was born at Beckington, a village about 3 miles north-east of Frome in Somerset, and was the eldest son of Joshua Parsons, a surgeon, who took much interest in the natural history of the district. The geological features are extremely varied, as within a walking distance of Beckington there can be studied the old Red Sandstone and Carboniferous rocks, the Trias, Lias, most of the Oolitic rocks, and Upper Cretaceous strata. After education in private schools Franklin Parsons proceeded to St. Mary's Hospital, and subsequently took high honours in medical subjects at the University of London, with the degree of M.D. in 1870. From 1867-73 he was engaged in medical practice with his father at Beckington, and devoted most of his leisure to the study of geology and botany. Some of his observations were communicated later on to the Somersetshire Archæological and Natural History Society in a paper on "The Flora of East Somerset" (1875), wherein he pointed out the relations between the geology and the distribution of the plants, and in another paper on the "Geology of the District around Bruton" (1879).

In 1874 Dr. Parsons was appointed Medical Officer of Health for the combined districts of Goole and Selby, in Yorkshire. Here he turned his attention to local natural history, to the warp of the Humber and its diatoms, the results being given to the Geological Society of the West Riding in papers on "The Maritime Plants and Tidal Rivers" (1876), and on "The Alluvial Strata of the Lower Ouse Valley" (1878). To the same Society he also communicated a paper on "The Trias of the Southern Part of the Vale of York" (1879).

Dr. Parsons was married in 1879 to the daughter of the late John Wells, J.P., of Booth Ferry House, Yorkshire, and the same vear was appointed a Medical Inspector on the Local Government Board. In this department he was frequently engaged on sanitary questions in which his knowledge of geology was of great practical service, as in connexion with sites for cemeteries and sewage-farms, with water-supply, pollution, and sundry epidemics. He prepared a "Memorandum on the Sanitary Requirements of Cemeteries", which was issued by the Local Government Board in 1880 and revised in 1906. In 1892 he became Assistant Medical Officer, being second in command on the Medical Staff of the Board, and this post, which included that of Inspector for General Sanitary Purposes, he held until his retirement early in 1911. Among his many official publications it will be appropriate here to mention his "Report on Geological Considerations in relation to Public Health and Sanitary Administration" (30th Ann. Rep. Loc. Gov. Board for 1900-1, 1902, p. 258). When President of the Epidemiological Society he 
delivered addresses on "Half a Century of Sanitary Progress and its Results" and "On the Comparative Mortality of English Districts". As remarked in the Laneet (November 8, 1913, p. 1356), "he probably influenced the sanitary development of this country more than anyone else." He was Examiner in Hrgiene and State Medicine for the University of London, and for the diploma of Public Health at Cambridge. He likewise served on various departmental committees, including the annual Consultatory Committee on the Geological Survey, under the Board of Education. To the Geological Survey he rendered much assistance in the matter of water supply, and his name appears on the title-page of memoirs dealing with the wells and borings in Lincolnshire, Suffolk, Kent, and Sussex (supplement). Dr. Parsons became a Fellow of the Geological Society in 1877, and a member of the Geologists' Association in 1911. He was an active member of the Croydon Natural History and Scientific Society, usually exhibiting at the meetings of the Geological Section some of the fossils which he had collected. As President for the year 1912 he delivered (on January 21 of this year) an address on "Plant Growth and Soil Conditions".

H. B. W.

\section{PROFESSOR DR. ANTON FRITSCH.}

WE regret to record the death of our old friend Professor Dr. Anton Fritsch, Director of the Royal Bohemian Natural History Museum, Prague, which took place on the morning of November 15. Dr. Fritsch had attained his 82 nd year, and we hope to give some account of his long scientific career next month.

\section{MISOHIIAATEOUS.}

Appointment of New Director to the Geological Sortey and Moseom.-The President of the Board of Education has appointed Dr. Aubrey Strahan, F.R.S., to be Director of the Geological Survey of Great Britain and Museum of Practical Geology, in succession to Dr. J. J. H. Teall, F.R.S., who will retire from the post on January 5 next. Dr. Strahan, who was born in 1852, was educated at Eton and St. John's College, Cambridge. He was elected a Fellow of the Royal Society in 1903, and is President of the Geological Society. He is the Assistant Director of the Geological Surrey of England and Wales.

Dr. Teall, who was born on January 5, 1849, has been Director of the Geological Survey and Museum since 1901. He is the author of British Petrography, a Description of the Rocks of the British Isles, 1888.

Kent Cost-Field.-Dr. Malcolm Burr has tabulated and printed in the Colliery Guardian for October 10, 1913, the available information as to the strata revealed by the borings at Tilmanstone, Guildford, Oxney, Maydensole, Ripple, Barfrestone, Goodnestone, Trapham, Woodnesborough, Stodmarsh, Walmestone, and Mattice Hill. We say 'available' because, as the author notes, many of the bores being made by chisel there were no 'cores' of the softer beds. Detailed reports are promised later by $\mathbf{M r}$. Arber and $\mathbf{M r}$. H. Bolton. 